TECTONICS, VOL. 11, NO. 4, PAGES 823-835, AUGUST 1992

\section{UPPER JURASSIC-LOWER CRETACEOUS BASINAL STRATA ALONG THE CORDILLERAN MARGIN: IMPLICATIONS FOR THE ACCRETIONARY HISTORY OF THE ALEXANDER-WRANGELLIA- PENINSULAR TERRANE}

William C. McClelland ${ }^{1}$ and George E. Gehrels Department of Geosciences, University of Arizona, Tucson

Jason B. Saleeby

Division of Geological and Planetary Sciences, California Institute of Technology, Pasadena

Abstract. Upper Jurassic and Lower Cretaceous basinal strata are preserved in a discontinuous belt along the inboard margin of the Alexander-WrangelliaPeninsular terrane (AWP) in Alaska and western Canada, on the outboard margin of terranes in the Canadian Cordillera accreted to North America prior to Late Jurassic time, and along the Cordilleran margin from southern Oregon to southern California. Nearly all of the basinal assemblages contain turbiditic strata deposited between Oxfordian and Albian time. Arc-type volcanic rocks and abundant volcanic detritus in many of the assemblages suggest deposition within or adjacent to a coeval arc complex. On the basis of the general similarities between the basinal sequences, we propose that they record involvement of the AWP in the Late Jurassic-Early Cretaceous evolution of the Cordilleran margin. A geologically reasonable scenario for the accretion of the AWP includes (1) Middle Jurassic accretion to the Cordilleran margin, in particular the Stikine and Yukon-Tanana terranes, in a dextral transpressional regime, (2) Late Jurassic-Early Cretaceous overall northward translation of the AWP and evolution of a series of transtensional basins within a complex dextral strike-slip system along the Cordilleran margin, and (3) mid-Cretaceous structural imbrication of the AWP and inboard terranes that either terminated or resulted in a change in the character of deposition in the marginal basins. Mid-Cretaceous deformation along the inboard margin of the AWP was broadly synchronous with contractional deformation throughout the Cordillera and most likely due to changes in subduction zone parameters along the Cordilleran margin, outboard of the AWP, rather than collision of the AWP.

\section{INTRODUCTION}

Terranes of the Canadian Cordillera [e.g., Coney et al., 1980] are typically divided into (1) fragments accreted to the continental margin prior to Late Jurassic time and (2) fragments structurally imbricated with inboard terranes during mid-Cretaceous (Albian-Cenomanian) time [e.g., Monger et al., 1982]. The Alexander,

\footnotetext{
${ }^{1}$ Now at Department of Geological Sciences, University of California, Santa Barbara.

Copyright 1992

by the American Geophysical Union.

Paper number 92TC00241.

0278-7407/92/92TC-00241\$10.00
}

Wrangellia, and Peninsular terranes, collectively referred to as the AWP (Figure 1), comprise the latter group. Mid-Cretaceous crustal shortening and high-pressure metamorphism involving the AWP and inboard terranes are cited by many workers as evidence for AWP accretion [Davis et al., 1978; Coney et al., 1980; Csejtey et al., 1982; Monger et al., 1982; Saleeby, 1983; Jones et al., 1986; Crawford et al., 1987; Brandon et al., 1988]. In contrast, arguments based on faunal and stratigraphic similarities and/or distribution of plutonic and volcanic arc rocks across terranes of the Canadian Cordillera have been used in models favoring pre-Early Cretaceous [e.g., Kleinspehn, 1985; Armstrong, 1988] or pre-Late Jurassic [e.g., Anderson, 1976; Jeletzky, 1984; Tipper, 1984; van der Heyden, 1992] accretion of the AWP. Additional models propose a Late Jurassic and/or Early Cretaceous migrating or zippering suture [e.g., Armstrong, 1988; Wernicke and Klepacki, 1988; Pavlis, 1989].

Gehrels and Saleeby [1985] suggested that a belt of discontinuous transtensional basins containing Upper Jurassic and Lower Cretaceous flyschlike clastic and volcanic strata evolved along the Cordilleran margin from southern Alaska to at least southern California during the northward migration of the AWP in Late JurassicEarly Cretaceous time. The following paper modifies and expands on these earlier ideas by summarizing the age and stratigraphic character of the basinal assemblages observed along the Cordilleran margin and the Middle Jurassic to mid-Cretaceous tectonic setting in which they evolved. The ensuing discussion presents a general model for the evolution of the marginal basins and accretionary history of the AWP.

\section{PRE-LATE JURASSIC EVOLUTION OF THE ALEXANDER-WRANGELLIA-PENINSULAR TERRANE}

The Alexander and Wrangellia terranes (Figure 1), originally defined by apparent differences in their Paleozoic to Late Triassic histories [Jones et al., 1972, 1977], were adjacent to one another by Pennsylvanian time (308 $\pm 6 \mathrm{Ma})$ [Gardner et al., 1988]. The earliest demonstrable ties between the Peninsular and Wrangellia terranes are Late Triassic in age [Plafker et al, 1989]. The Paleozoic basement history of the Alexander terrane, which is the most complete of the AWP triad, indicates that the crustal fragment evolved as an island arc complex, perhaps in proximity to the Gondwana orogenic system prior to Devonian time [Gehrels and Saleeby, 1987]. Nd isotopic studies suggest an intraoceanic environment for the Alexander-Wrangellia terrane through Late Triassic time [Samson et al., 1989, 1990].

Paleomagnetic data from Wrangellia [Hillhouse and Grommé, 1984] and the Alexander terrane [Haeussler et al., 1989] suggest that the AWP was located approximately $10^{\circ}$ to $20^{\circ}$ north or south of the paleoequator during Late Triassic time. Assuming a northern Late Triassic paleolatitude, paleomagnetic data for southern Wrangellia (Vancouver Island) are not discordant with respect to North America [May and Butler, 1986]. There are, however, no rigorous constraints on the choice of northern versus southern hemisphere Late Triassic position for the AWP. The southern option is favored on the basis of reported differences between Late Triassic AWP and North American fauna [Tozer, 1982; Newton, 1983; Silberling, 1985]. Placing the AWP in an equatorial eastern Pacific position within the faunal realm of the South American 
margin (southern hemisphere) in Late Triassic time is consistent with these differences.

Comparison of Pliensbachian ammonites suggests a northern hemisphere position and latitudinal

displacement of approximately $2400 \mathrm{~km}$ with respect to
North America for Wrangellia during Early Jurassic time [Taylor et al., 1984; Smith and Tipper, 1986]. On the basis of faunal and stratigraphic similarities between Callovian basinal strata observed from Wrangellia to the craton, Tipper [1984] and Jeletzky [1984] argued that

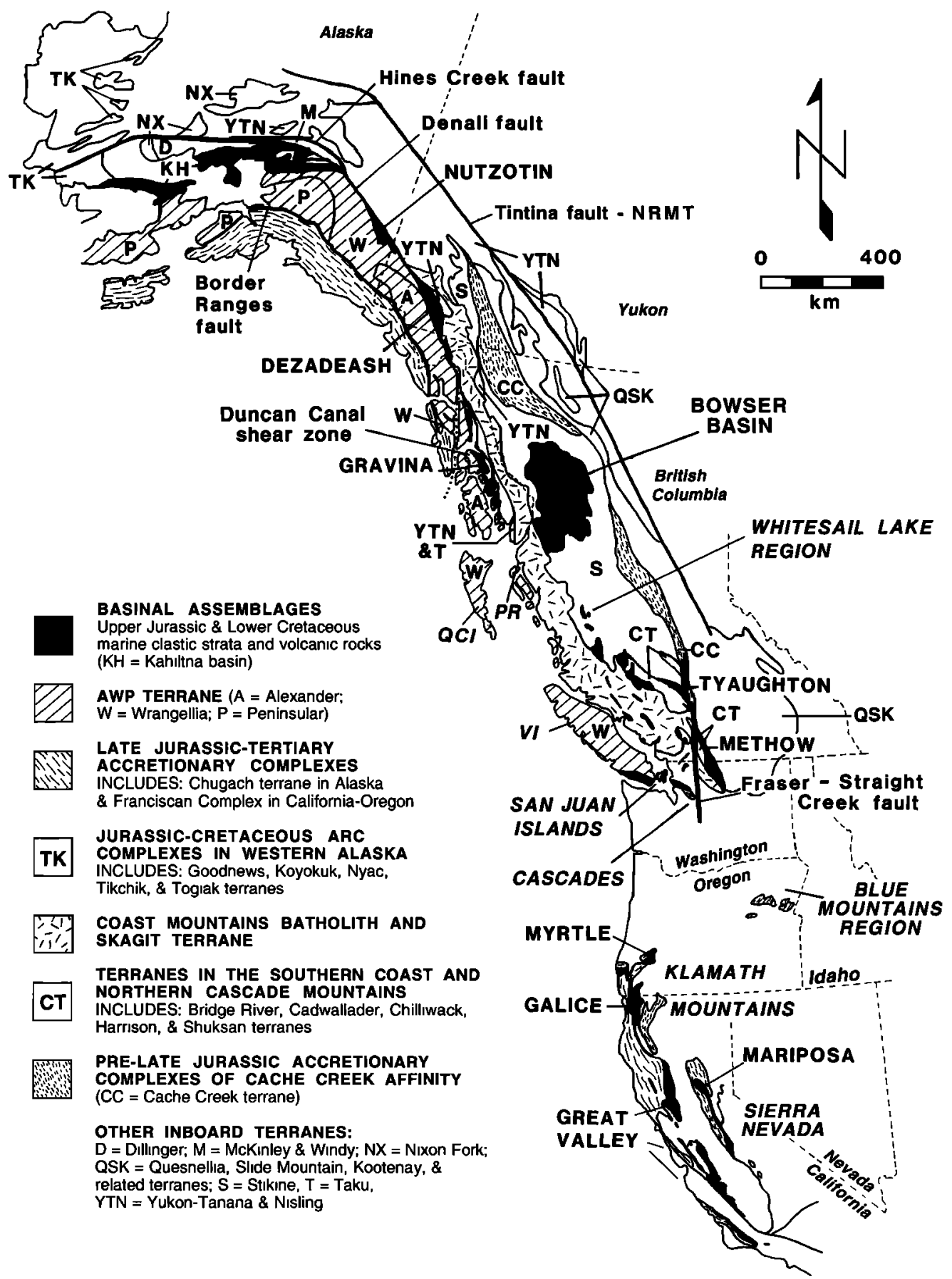

Fig. 1. Generalizcd terrane map of the western Cordillera showing the distribution of the Upper Jurassic-Lower Cretaceous basinal assemblages and geographic regions discussed in the text. Figure is modified after Jones et al. [1987], Wheeler et al. [1988], and Silberling et al. [1987]. Abbreviations are NMRT, northern Rocky Mountain trench; PR, Prince Rupert; QCI, Queen Charlotte Islands; and VI, Vancouver Island. Other abbreviations are defined in the legend. 
Wrangellia was near its present position relative to cratonal North America by late Middle Jurassic time. Paleomagnetic data from Upper Jurassic clastic strata (Naknek Formation) indicate $3500( \pm 1000) \mathrm{km}$ of postJurassic northward translation for the Peninsular terrane [Stone and McWilliams, 1989] using the reference pole of Gordon et al. [1984]. Recalculating the estimate using the Glance Conglomerate reference pole [May and Butler, 1986] and accounting for possible inclination error induced during deposition and compaction [Coe et al., 1985] yields nearly concordant results. Thus significant post-Jurassic latitudinal translation of the Peninsular terrane relative to North America is permissible but not required. From the constraints outlined above, we conclude'that the AWP was most likely positioned in the eastern Pacific basin, south $\left(\approx 30^{\circ}\right)$ of the North American margin, during Late Triassic time and moved northward to near its present position with respect to cratonal North America by Late Jurassic time.

\section{MIDDLE JURASSIC TECTONISM ALONG THE CORDILLERAN MARGIN}

Middle Jurassic accretionary events in the Canadian Cordillera include (1) east directed thrusting of the Quesnellia, Yukon-Tanana and Slide Mountain terranes over cratonal North America [Price, 1981; Monger et al., 1982; Brown et al., 1986; Armstrong, 1988], (2) obduction of the Cache Creek terrane onto Stikine and Quesnellia [e.g., Mortimer, 1986; Cordey et al., 1987], and (3) amalgamation of the Stikine, Bridge River, and Cadwallader terranes [Rusmore et al., 1988] (Figure 1). Although strongly modified by late Mesozoic and Cenozoic tectonism, all terranes inboard of the AWP in the Canadian Cordillera appear to be tied to North America with no intervening subduction zones by Late Jurassic time. Terranes outboard of North American basement in Blue Mountains region of northeastern Oregon and western Idaho (Figure 1) were reportedly amalgamated during or prior to Late Jurassic time [e.g., Avé Lallemant, 1992] and accreted to North America during Early Cretaceous time [Lund and Snee, 1988]. By analogy with correlative terranes in the Canadian Cordillera (see review by Oldow et al. [1989]), we assume that these terranes were accreted to North America by Late Jurassic time. Early to mid-Cretaceous (118-88 Ma) deformation along the Salmon River suture zone [Lund and Snee, 1988] most likely reflects modification of the original accretionary boundary. A Middle Jurassic arc in the Klamath-Sierra Nevada region (Figure 1) was constructed on a diverse basement of previously accreted Paleozoic and Upper Triassic-Lower Jurassic arc fragments and mélange complexes (see reviews by Burchfiel et al. [1992] and Saleeby and BusbySpera [1992]). The arc complex, active from approximately 177 to $159 \mathrm{Ma}$, was deformed during a west-vergent contractional event between 169 and $161 \mathrm{Ma}$ [Wright and Fahan, 1988].

Middle Jurassic deformation in the Alexander terrane is recorded by a dextral transpressional shear zone (Duncan Canal shear zone of McClelland and Gehrels [1990]) in central southeastern Alaska (Figure 1) and imbrication of the Alexander terrane and metamorphic rocks equivalent to the Yukon-Tanana terrane in southern southeastern Alaska [Saleeby and Rubin, 1990]. Southwest directed Middle Jurassic (Aalenian-Bajocian) compressional deformation of Wrangellia is observed on the Queen Charlotte Islands [Lewis et al., 1991].
Deformation of similar age may be recorded by the Middle Jurassic Kotsina conglomerate in the Wrangellia and Peninsular terranes in southern Alaska [Plafker et al., 1989].

Middle Jurassic deformation and terrane accretion along the Cordilleran margin marked the demise of a west facing late Paleozoic-Early Jurassic fringing arc complex represented by disrupted arc and oceanic assemblages of Cache Creek affinity (Figure 1) and generally inboard island arc sequences (McCloud belt) [Miller, 1987, and references therein]. The pre-Middle Jurassic position of the Stikine terrane relative to rocks of Cache Creek affinity is uncertain (compare Wernicke and Klepacki [1988] and Oldow et al. [1989]). We assume that it occupied its present position relative to inboard terranes by Late Jurassic time. On the basis of evidence for imbrication of the Alexander and YukonTanana terranes and widespread deformation within the AWP, we conclude that the AWP was involved in Middle Jurassic deformation and accretion observed along the Cordilleran margin.

\section{UPPER JURASSIC-LOWER CRETACEOUS BASINAL ASSEMBLAGES}

Variably deformed Upper Jurassic-Lower Cretaceous basinal assemblages are preserved along the AWP suture zone from southern Alaska to southern British Columbia and along the Cordilleran margin at least as far south as the Klamath-Sierra Nevada region (Figure 1). Individual assemblages differ in pre-Upper Jurassic basement rocks, provenance, and detailed stratigraphy, but a common evolution and tectonic setting are inferred from the general similarity in age and lithologic character.

\section{Alaska-Northwestem Canada}

Southem Alaska. The Kahiltna terrane (Figure 1) includes Kimmeridgian to Valanginian volcaniclastic turbidites of the Koksetna River sequence (Figure 2a) [Wallace et al., 1989] and clastic strata as young as Cenomanian that are structurally intermixed with small blocks of Triassic and older strata of uncertain origin [Jones et al., 1982]. The Koksetna River sequence apparently was derived from and deposited on the Peninsular terrane [Wallace et al., 1989]. At its southern margin, the Kahiltna terrane is separated from the Wrangellia and Peninsular terranes by southeast dipping mid-Cretaceous thrust faults [e.g., Csejtey et al., 1982; Nokleberg et al., 1985]. The Kahiltna terrane is currently juxtaposed with the Yukon-Tanana and other terranes to the north along the Denali, Hines Creek, and Chilchitna faults (Figure 1). Depositional ties between the Kahiltna basin and the northern terranes have not been documented. Stanley et al. [1990] suggested that the Wrangellia and Kahiltna terranes were underthrust beneath the Yukon-Tanana terrane to the north during mid-Cretaceous time. Significant pre-Late Cretaceous (pre-95 Ma) displacement along the Hines Creek fault [Wahrhaftig et al., 1975] indicates that mid-Cretaceous contractional deformation was accompanied by dextral strike-slip translation.

Eastern Alaska. Oxfordian to Barremian volcaniclastic turbidites of the Nutzotin Mountains sequence in eastern Alaska (Figures 1 and $2 b$ ) unconformably overlie and were in part shed from Wrangellia [Berg et al., 1972]. These rocks, apparently deposited in a northeastward deepening basin, are overlain by Lower Cretaceous arc 

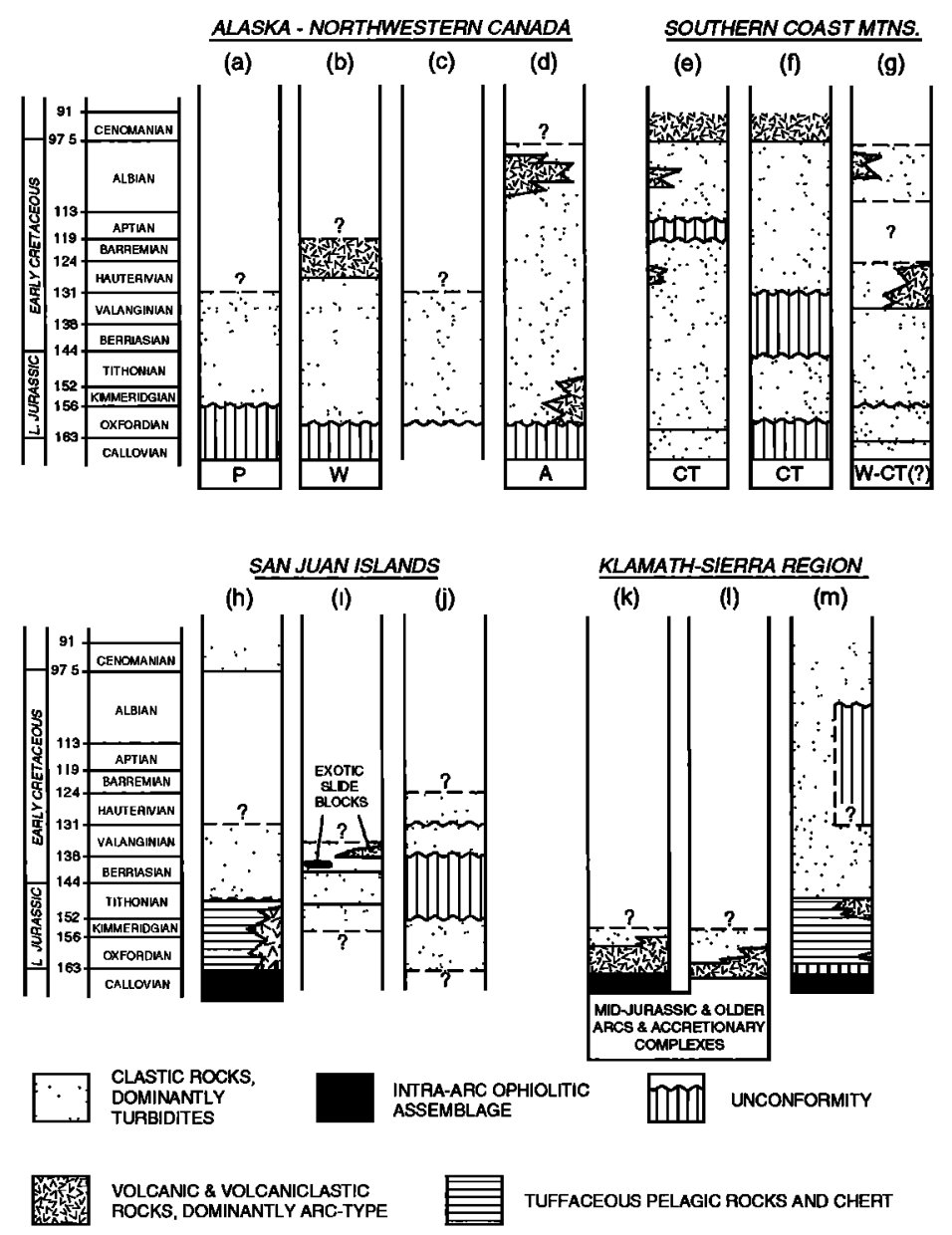

Fig. 2. Generalized columns compiling known or inferred age (time scale of Palmer [1983]) and basement of Upper Jurassic-Lower Cretaceous clastic and arc-type volcanic rocks in the (a) Kahiltna terrane, (b) Nutzotin Mountains sequence and Chisana Formation, (c) Dezadeash Formation, (d) Gravina belt, (e) Tyaughton basin, (f) Methow basin, (g) Harrison Lake region (Gambier Group), (h) Decatur terrane, (i) Constitution Formation, (j) Spieden Group, (k) Galice Formation, (l) Mariposa Formation, and (m) Great Valley sequence. See Figure 1 for locations and basement terrane abbreviations. Columns adapted from Arthur [1986]-g; Berg et al. [1972]b, c, d; Brandon et al. [1988]-h, i, j; Eisbacher [1976]-c; Garver [1988a, 1989]-e, h; Harper and Wright [1984]-k; Hopson et al. [1981, unpublished data, 1992]-m; Johnson [1981]-j; McClelland et al. [1992a]-d; McGroder et al. [1990]-f; Saleeby [1986]-l, m; Sharp [1988]-l; Wallace et al. [1989]a; and other references cited in text.

volcanic and volcaniclastic rocks of the Chisana Formation that may record east directed subduction beneath the outboard margin of the AWP [Berg et al., 1972; Barker, 1988]. Similar but unfossiliferous volcanic and volcaniclastic strata along the Denali fault mark the northwestern continuation of this belt [Nokleberg et al., 1985].

The Dezadeash Formation, exposed northeast of the Denali fault in Yukon (Figure 1), comprises Oxfordian to Valanginian argillite and graywacke turbidites (Figure 2c) that were derived from a source area to the southwest and are likely correlative with the Nutzotin Mountains sequence [Eisbacher, 1976]. The Dezadeash strata are structurally overlain to the northeast by the Kluane schist which may have been in part derived from the Dezadeash turbidites. We infer that metamorphism and imbrication of the Kluane schist and Dezadeash Formation are related to mid-Cretaceous deformation similar to that observed in southern and southeastern Alaska. Stratigraphic relationships between the Dezadeash Formation and inboard terranes (YukonTanana) have not been demonstrated.

Southeastem Alaska. The Gravina belt in southeastern Alaska (Figure 1) includes Oxfordian to Albian (and possibly Cenomanian) argillite, volcaniclithic graywacke turbidites, and minor conglomerate (Figure 2d) [Berg et al., 1972; Brew and Karl, 1988; Gehrels et al., 1992]. Mafic volcanic rocks are dominantly Early Cretaceous in age [e.g., Brew and Karl, 1988; Gehrels et al., 1992] but are in part of probable Late Jurassic age [e.g., Rubin and Saleeby, 1991b; McClelland et al., 1992a]. Berg et al. [1972] and most subsequent workers concluded that the Gravina belt depositionally overlies the Alexander terrane. To the east, the Gravina belt is separated from the YukonTanana, Stikine, and Taku terranes by east dipping mid- 
Cretaceous thrust faults [Gehrels et al., 1990, 1992; Rubin et al., 1990; Rubin and Saleeby, 1992; McClelland et al., 1992b]. Gravina strata reportedly depositionally overlie the Taku terrane [Rubin and Saleeby, 1991a] and detrital zircon studies suggest that the Gravina belt received detritus from and therefore may have depositionally overlain the Yukon-Tanana and Stikine terranes [Gehrels and Greig, 1991].

The Gravina-Nutzotin belt is inferred to have been deposited in an intra-arc basinal setting [Berg et al., 1972; Rubin and Saleeby, 1991b; McClelland et al., 1992a]. Late Jurassic and Early Cretaceous plutons representing intrusive components of the arc system intruded the Wrangellia and Alexander terranes in southeastern Alaska [Berg et al., 1972; Gehrels and Berg, 1988]. In southern Alaska and Yukon, the arc is expressed as the Tonsina-Chichagof belt [Hudson, 1983] and Saint Elias suite [Dodds and Campbell, 1988]. Tithonian-Valanginian components of the Chugach terrane including the McHugh Complex in southern Alaska are preserved outboard of the AWP as scattered fragments along the Border Ranges fault (Figure 1). These fragments are interpreted as remnants of the accretionary complex associated with the west facing Gravina-Nuzotin arc [Berg et al., 1972; Pavlis, 1982; Gehrels and Berg, 1988; Plafker et al., 1989]. Likely candidates for the northern or western continuation of the basinal arc complex include Late Jurassic-Early Cretaceous arc fragments in the Togiak, Nyac, and Koyukuk terranes in western Alaska (Figure 1) [Box and Patton, 1989; Plafker et al., 1989; Wallace et al., 1989].

Central British Columbia. Clastic strata that are probably correlative with the Gravina belt are observed west of the Coast Mountains batholith as far south as the Prince Rupert region (Figure 1) [Woodsworth and Orchard, 1985; Crawford et al., 1987]. Extension of these rocks into the batholith at this latitude has been proposed through correlation of the Khutzeymateen Group with the Gravina belt [Douglas, 1986]. This correlation is tenuous since quartzite observed in this sequence is characteristic of rocks equivalent to the Yukon-Tanana terrane in the Prince Rupert region [M. L. Crawford, personal communication, 1988; Gareau, 1991] rather than the Gravina belt. Late Jurassic and Early Cretaceous plutons representing the southern continuation of the Gravina arc are observed south of Prince Rupert [van der Heyden, 1992] and on the Queen Charlotte Islands (Figure 1) [Anderson and Greig, 1989]. Tithonian to Upper Cretaceous clastic strata on the Queen Charlotte Islands are inferred to have been deposited in a forearc setting, west of the Early Cretaceous arc [Haggart, 1991; Lewis et al., 1991]. An influx of Upper Cretaceous conglomerates (Honna Formation) likely reflects uplift of the Coast Mountains due to mid-Cretaceous crustal thickening [Higgs, 1990, and references therein].

Middle Jurassic (Bathonian) to Cenomanian marine and nonmarine clastic and minor volcanic rocks are preserved east of the Coast Mountains in the Bowser Basin (Figure 1) [Evenchick, 1991, and references therein]. This sequence was likely deposited in a foredeep formed in response to Middle Jurassic west directed emplacement of the Cache Creek terrane on the Stikine terrane [e.g., Eisbacher, 1985]. Bathonian to Kimmeridgian and Hauterivian to Albian volcaniclastic and volcanic rocks along the western margin of the Bowser Basin [Anderson, 1989; Bassett, 1991] may record proximity of the basin to the Late Jurassic-Early Cretaceous arc developed on the AWP to the west.
Southern Coast Mountains, Cascades, and San Juan Islands

Upper Jurassic-Lower Cretaceous strata in the southern Coast Mountains, northwest Cascades, and the San Juan Islands are generally coeval but vary in stratigraphy and basement character. They are divided into (1) the Tyaughton-Methow basin which is likely tied to the Stikine and inboard terranes, (2) strata associated with varied Middle Jurassic and older arc terranes in the southern Coast Mountains and northern Cascades, and (3) a western assemblage associated with disrupted complexes and Middle-Late Jurassic ophiolitic rocks in the San Juan Islands and western Cascades (Figure 1).

Tyoughton-Methow basin. The Tyaughton and Methow basins, offset approximately $100 \mathrm{~km}$ by dextral displacement on the Fraser-Straight Creek fault system (Figure 1) [Price et al., 1985; Kleinspehn, 1985], include Oxfordian to Albian volcaniclastic sandstone, siltstone, argillite, and conglomerate with minor andesitic volcanic rocks (Figures 2e and 2f) [Garver, 1989; Umhoefer, 1989; McGroder et al., 1990, and references therein]. Callovian Tyaughton strata apparently depositionally overlie the Cadwallader terrane [Rusmore et al., 1988] which is correlative with the Stikine terrane [Umhoefer, 1990; Rusmore and Woodsworth, 1991]. Oxfordian and younger strata in the Methow basin are separated from adjacent terranes by the Ross Lake, Hozameen, and Pasayten faults. Lithologic similarities between Lower to Middle Jurassic strata in the Methow basin (Ladner Group) and coeval strata to the east (Ashcroft Formation) [Monger, 1986; McGroder, 1991] suggest deposition of Upper Jurassic and younger Methow strata on or at least near the accreted Quesnellia, Stikine, and Cache Creek terranes. Strata within the Tyaughton and Methow basins were apparently derived from an eastern source until Albian time [e.g., Kleinspehn, 1985] although Jeletzky and Tipper [1968] suggested that Hauterivian strata in the Tyaughton basin were in part westerly derived. Clastic rocks in the western Tyaughton basin interfinger with Lower Cretaceous volcanic rocks indicating that the Tyaughton basin may have been bounded by a volcanic arc to the west [Garver et al., 1988]. A major change in Tyaughton-Methow sedimentation in Albian time reflected by a double-sided (west and east) infilling of coarse clastic material [Garver, 1989] was coincident with the development of the mid-Cretaceous eastern Cascades fold belt [McGroder, 1989].

Southem Coast Mountains and north central Cascades. Mafic and minor felsic volcanic rocks, volcaniclastic graywacke, and argillite of the Gambier assemblage (including the Nooksack Group) range from Oxfordian to Albian in age [e.g., Misch, 1966; Wheeler and McFeely, 1987; Woodsworth and Monger, 1992]. Gambier strata in the southern Coast Mountains and northern Cascades occur as fault slices in a west-vergent mid-Cretaceous thrust system [e.g., Misch, 1966; Brandon et al., 1988; Journeay, 1990]. Oxfordian to Valanginian volcaniclastic rocks and Lower Cretaceous volcanic rocks west of Harrison Lake (Figure 2g) [Arthur, 1986; Monger, 1989] stratigraphically overlie the Middle Jurassic Harrison Lake Formation which is likely correlative with strata in Wrangellia [Friedman et al., 1990]. HauterivianBarremian arc-type volcanic and volcaniclastic rocks, largely preserved as pendants, are widespread across the Coast Mountains [Woodsworth and Monger, 1992]. Gambier strata in the east central Coast Mountains are 
juxtaposed against the Stikine terrane along east-vergent Late Cretaceous thrust faults [Crawford et al., 1987; Rusmore and Woodsworth, 1989; van der Heyden, 1992] such that primary stratigraphic relationships between the Stikine terrane and Gambier assemblage are uncertain. Lower Cretaceous calc-alkaline volcanic rocks in the Gambier assemblage and Late Jurassic (165-145 Ma) and Early Cretaceous (120-114 Ma) plutons [Armstrong, 1988; Friedman, 1989; van der Heyden, 1992] in Wrangellia mark the southern continuation of the Gravina arc. In the Whitesail Lake region (Figure 1), Late Jurassic plutons intrude metamorphic rocks likely derived from the Stikine terrane and thus provide an additional Late Jurassic link between the AWP and Stikine terranes [van der Heyden, 1992]. We infer that the Gambier arc evolved along the eastern edge of Wrangellia and western margin of the TyaughtonMethow basin on the Stikine and Quesnellia terranes.

San Juan Islands. Upper Jurassic-Lower Cretaceous strata comprising the Constitution Formation, Lummi Group, and Spieden Group are preserved in thrust slices of the mid-Cretaceous northwest Cascades-San Juan thrust system (Figure 1). Although these units and their basement assemblages are fault-bounded, most are similar to other components in the Cordillera.

The Decatur terrane includes the Fidalgo Complex and Lummi Group (Figure 2h) [Garver, 1988a, and references therein]. Back-arc ophiolitic basement of the Fidalgo Complex is intruded by arc-related plutons and overlain by volcanic rocks of Callovian to Oxfordian age [Brandon et al., 1988; Garver, 1988a]. The volcanic sequence is interlayered with and overlain by Oxfordian to Tithonian argillite, chert, and volcaniclastic rocks that are in turn unconformably overlain by Tithonian to Valanginian volcaniclastic strata of the Lummi Group [Garver, 1988a]. The Fidalgo Complex and similar ophiolitic complexes in the western and central Cascades [Whetten et al., 1980; Miller, 1985] may have evolved as small pull-apart segments along transform faults [e.g., Brandon et al., 1988]. Direct correlation of the Lummi Group-Fidalgo Complex with the Great Valley sequenceCoast Range ophiolite (described below) proposed by Garver [1988b] implies significant northward translation of the Fidalgo Complex during Hauterivian to Aptian time. Similar northward translation has been proposed for blueschist-grade metamorphic rocks of the Shuksan metamorphic suite in the Cascades [Brown and Blake, 1987] and clastic rocks of the western mélange belt in the western Cascades [Jett and Heller, 1988].

The Constitution Formation consists of Upper Jurassic-Lower Cretaceous volcaniclastic sandstone, mudstone, chert, and minor pillow basalt (Figure 2i) [Brandon et al., 1988]. Although currently faultbounded, the presence of detritus and slide blocks likely shed from adjacent terranes in the San Juan Islands and northern Cascades suggests deposition of the sequence near the Cordilleran margin [Brandon et al., 1988]. The Constitution Formation is similar to the Pacific Rim Complex and Pandora Peak unit on Vancouver Island [Rusmore and Cowan, 1985; Brandon, 1989], western mélange belt in the western Cascades (see Tabor et al. [1989] for review), Rimrock Lake inlier in the southern Cascades [Miller, 1989], and Yolla Bolly terrane (part of the Franciscan Complex) in southwestern Oregon and California [e.g., Blake et al., 1985]. Although distinct in stratigraphic detail, most of these assemblages are associated with or contain detritus from Late Jurassic arc complexes. The mélanges are inferred to have formed in a complex dextral strike-slip fault system active in the forearc region of the Early Cretaceous arc along the Cordilleran margin [e.g., Rusmore and Cowan, 1985; Brandon, 1989].

Oxfordian to Hauterivian volcaniclastic strata, breccia and conglomerate of the Spieden Group were deposited within or adjacent to a Late Jurassic arc complex (Figure 2j) [Johnson, 1981]. The Spieden Group presently lies within the footwall of the San Juan thrust system, but correlation of these rocks with Wrangellia is uncertain [Brandon et al., 1988]. Callovian to Albian clastic rocks of Wrangellia on Vancouver Island (Figure 1) lack evidence for coeval arc volcanism and may be in part correlative with forearc strata on the Queen Charlotte Islands [Muller et al., 1981]. Similarities with coeval rocks in the Harrison Lake region [Johnson, 1981] suggest that the Spieden Group was deposited along the western flank of the Gambier arc.

\section{Blue Mountains Region}

Callovian to Oxfordian turbidites in the Blue Mountains region (Figure 1) overlie Middle Jurassic forearc deposits and older arc assemblages in the Wallawa (also Seven Devils) and Izee terranes [Vallier, 1977; Dickinson and Thayer, 1978]. Late Jurassic-Early Cretaceous basinal rocks are absent in this region, presumably due to Late Jurassic deformation [e.g., Avé Lallemant, 1992] that was followed by emplacement of Early Cretaceous (144 Ma and younger) arc-related plutons (N. W. Walker, personal communication, 1992). Widespread deposition of Albian to Cenomanian synorogenic conglomerate reflects mid-Cretaceous deformation [Lund and Snee, 1988, and references therein].

\section{Sierra Nevada-Klamath Mountains Region}

Upper Jurassic-Lower Cretaceous basinal strata in the Klamath Mountains and western Sierra Nevada region include the Galice and Mariposa formations, Great Valley sequence, and Myrtle Group (Figure 1). These clastic strata are typically underlain by Middleearly Late Jurassic ophiolites and coeval volcanic arc complexes. In the Klamath Mountains, the Galice Formation and related units consist of argillite, volcaniclastic graywacke, and minor conglomerate and chert of late Oxfordian-early Kimmeridgian to latest Jurassic age (Figure 2k) [e.g., Harper and Wright, 1984; Wyld and Wright, 1988]. This sequence and its probable equivalents depositionally overlie the $161-164 \mathrm{Ma}$ Josephine and Devils Elbow ophiolites [Saleeby, 1982, 1992; Harper and Wright, 1984; Wright and Wyld, 1986; Wyld and Wright, 1988] and possibly the Preston Peak mafic complex [Snoke, 1977]. In addition, the clastic rocks interfinger with and overlie the Rogue arc sequence [Garcia, 1982]. Oxfordian to lower Kimmeridgian slate, graywacke, and argillite in the western Sierra Nevada foothills region (Mariposa Formation) typically contain abundant chert and metamorphic clasts but at least locally contain a significant volcanic component (Figure 2l) [Saleeby, 1986; Sharp, 1988]. These rocks overlie and interfinger with Callovian to lower Oxfordian volcanic rocks deposited within an extensional arc constructed on Middle Jurassic and older ophiolite mélange basement of the Sierran foothills and Calaveras chert and argillite mélange [Saleeby and Busby-Spera, 1992, and references therein]. 
Upper Tithonian to Valanginian turbiditic strata of the basal Great Valley sequence overlie Oxfordian to Tithonian pelagic, volcanic, and volcaniclastic rocks and the 170-160 Ma Coast Range ophiolite (Figure $2 \mathrm{~m}$ ) [e.g., Hopson et al., 1981, 1991]. The turbidites are dominated by chert and metamorphic detritus shed from the adjacent Cordilleran margin [Dickinson and Rich, 1972; Ingersoll, 1983; Seiders, 1988]. The Wild Rogue ophiolite and overlying arc-type volcanic rocks and Upper Jurassic-Lower Cretaceous clastic strata (Myrtle Group) in southwestern Oregon (Figure 1) are similar to the Coast Range ophiolite and Great Valley sequence [Blake et al., 1985; Saleeby, 1992].

Middle to Late Jurassic ophiolites and extensional arc complexes in the Klamath-Sierra Nevada region are interpreted to have formed in a forearc to intra-arc and interarc transtensional rift system beginning at approximately $170 \mathrm{Ma}$ (Bathonian) and continuing to early Oxfordian time [Saleeby, 1992, and references therein]. Most of the ophiolites are clearly associated with arc complexes but some ocean floor remnants, such as the Point Sal (southern Coast Range) ophiolite, are separated from overlying arc-related rocks by a substantial hiatus and remained distal to arc sedimentation [Hopson et al., 1991]. Arc volcanics were typically onlapped by turbiditic strata between Oxfordian and Tithonian time. Late Jurassic deformation in the Klamath-Sierra Nevada region terminated clastic deposition of the Galice and Mariposa Formations and is reflected by a change in basin geometry and deposition of the lower Great Valley sequence.

\section{OVERVIEW OF THE UPPER JURASSIC-LOWER CRETACEOUS BASINAL ASSEMBLAGES}

Upper Jurassic-Lower Cretaceous basinal assemblages along the Cordilleran margin from southern Alaska to southern California are divided into three main groups based on their basement character: (1) those deposited on the eastern edge of the AWP, (2) those deposited on inboard terranes that were accreted to North America prior to Late Jurassic time, and (3) those deposited on Middle-Late Jurassic ophiolitic basement or pre-Late Jurassic accretionary complexes. Despite variance in local provenance, stratigaphy, and basement type, the basinal assemblages share several common elements: (1) sedimentation in all of the basins initiated or changed in character during Oxfordian-Kimmeridgian time, (2) deposition of arc-type volcanic rocks or detritus shed from coeval arc complexes in many of the basins during Oxfordian-Albian time, and (3) clastic sedimentation in all of the basins changed in character during midCretaceous time. Products of Late Jurassic-Early Cretaceous arc magmatism are preserved in the AWP, southwestern Stikine terrane, and the Klamath-Sierra Nevada region. The clastic basins are inferred to have evolved in close association with this arc system which records northeast directed subduction along the Cordilleran margin from Late Jurassic to mid-Cretaceous time [e.g., Engebretson et al., 1985].

\section{ACCRETIONARY HISTORY OF THE AWP}

The following section discusses a geologically reasonable scenario for the Middle Jurassic accretion and northward migration of the AWP along the Cordilleran margin during Late Jurassic-Early Cretaceous time. It is by no means a unique solution to the accretion of the
AWP and is similar in some aspects to models presented by Saleeby and Gehrels [1988], Brandon et al. [1988], Pavlis [1989], Plafker et al., [1989], Wallace et al. [1989], van der Heyden [1992], Burchfiel et al. [1992], Saleeby and Busby-Spera [1992], and others.

As outlined above, paleobiogeographic and paleomagnetic data suggest that the AWP was considerably south of its present location with respect to North America in Late Triassic time and migrated northward during Late Triassic-Middle Jurassic time. Accretion of the AWP to the Cordilleran margin prior to Late Jurassic time is suggested by (1) imbrication of the Alexander and Yukon-Tanana terranes and deformation within the AWP prior to deposition of Oxfordian strata in the Gravina basin [McClelland and Gehrels, 1990; Saleeby and Rubin, 1990], (2) emplacement of Late Jurassic arc-related plutons in both the Wrangellia and Stikine terranes [Armstrong, 1988; van der Heyden, 1992], (3) the presence of detritus derived from the Yukon-Tanana and Stikine terranes in the Gravina belt [Gehrels and Greig, 1991] and clasts derived from the Quesnellia-equivalent(?) Chilliwack terrane in Middle Jurassic Wrangellia-equivalent strata beneath the Gambier assemblage in the Harrison Lake region [Monger, 1989; Friedman et al., 1990]. Since there is currently no evidence for a subduction complex separating the AWP and Stikine terrane, we conclude that the initial Middle Jurassic AWP-Cordilleran margin juxtaposition resulted from either oblique subduction along the margin south of the Stikine terrane followed by northward displacement along a dextral strike-slip fault system or migration of the AWP along the Cordilleran margin as a forearc fragment above a coeval east dipping subduction zone (see Saleeby and Busby-Spera [1992] for discussion). Oblique or transpressional accretion of the AWP, most likely along the paleo-Oregon-Washington margin, was apparently synchronous with Middle Jurassic accretion of the Stikine and inboard terranes. Middle Jurassic contractional deformation in the Klamath-Sierra Nevada region may record accretion of the southern AWP terrane [Saleeby and Busby-Spera, 1992].

Following Butler et al. [1989], we favor Middle Jurassic accretion of the AWP and Stikine terrane within 1000 $\mathrm{km}$ of their present position with respect to North America rather than $\geq 2400 \mathrm{~km}$ to the south as implied by the Baja British Columbia model of Umhoefer [1987].

Closely following accretion of the AWP, arc magmatism in all but the westernmost portion of the Stikine terrane ceased [Armstrong, 1988] and Late Jurassic arc magmatism apparently shifted westward to the AWP (Figure 3a). This westward shift likely reflects initiation or resumption of east directed subduction outboard of the AWP that is recorded by the oldest accretionary complex fragments preserved in the Chugach terrane. The Late Jurassic arc constructed on the AWP and Stikine terranes mark the northern continuation of the Late Jurassic Klamath-Sierra Nevada arc. Along the southern segment of the arc, Callovian to early Oxfordian interarc to forearc ophiolite complexes evolved within a dextral transtensional regime during or immediately following AWP accretion (Figure 3a) [Saleeby, 1992]. The ophiolites and their overlying pelagic and volcanic cover moved rapidly northward in early Late Jurassic time [Hopson et al., 1991; Pessagno and Blome, 1990] within the margin-parallel transform system. The dextral fault system is inferred to have extended northward along the AWP-Cordilleran margin suture zone utilizing the pre-Late Jurassic accretion- 


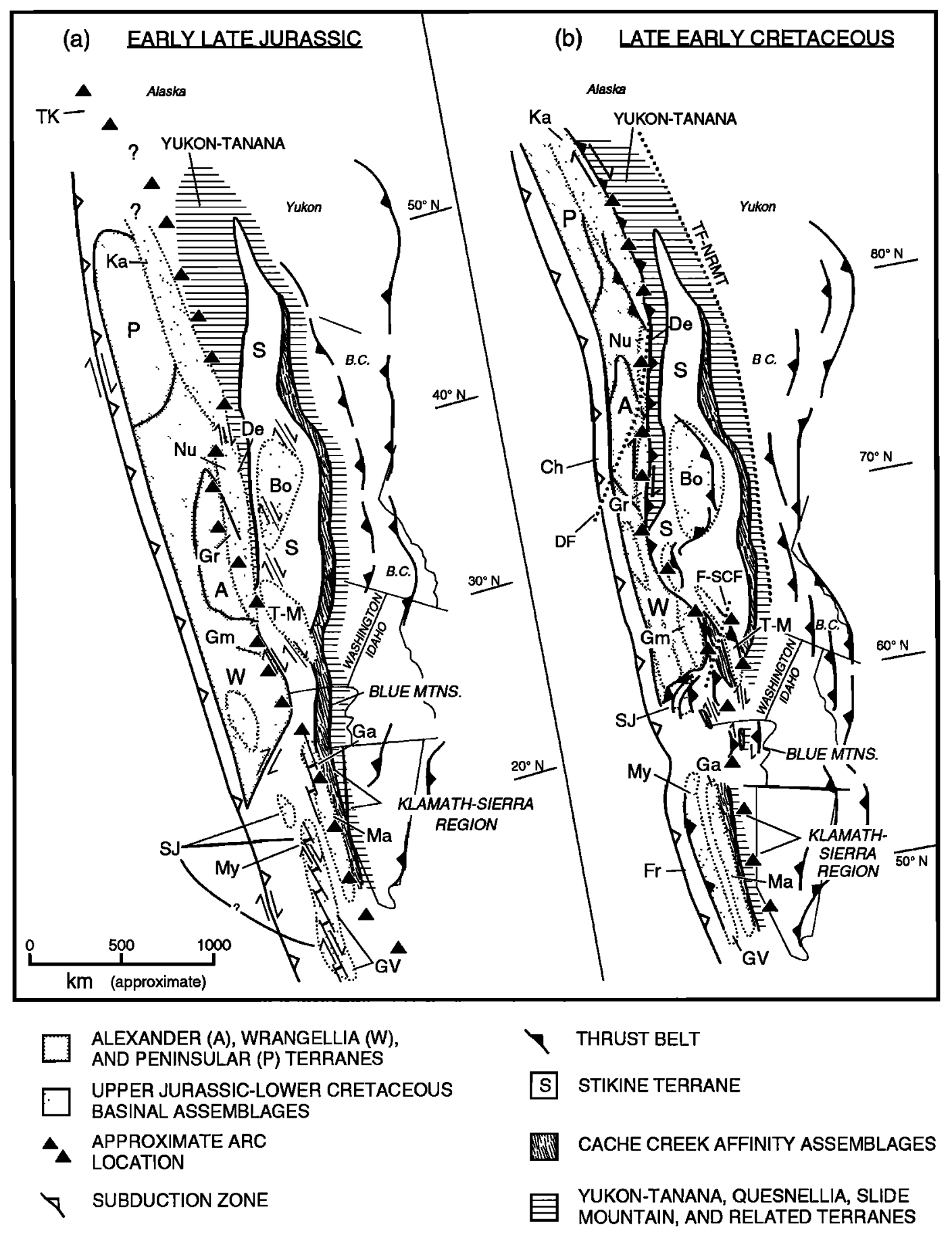

Fig. 3. Schematic reconstructions depicting inferred relations along the Cordilleran margin during (a) early Late Jurassic and (b) late Early Cretaceous time. Basinal assemblages are Bo, Bowser Basin; De, Dezadeash; Ga, Galice; Gm, Gambier; Gr, Gravina; GV, Great Valley; Ka, Kahiltna; Ma, Mariposa; My, Myrtle; Nu, Nutzotin; SJ, Lummi and Constitution; and T-M, TyaughtonMethow. Accretionary complexes are $\mathrm{Ch}$, Chugach terrane and $\mathrm{Fr}$, Franciscan Complex. The sketches are not intended to be palinspastic reconstructions; however, the mid-Cretaceous configuration of major terranes is approximated assuming the following Late Cretaceous-Tertiary displacements: Tintina fault-northern Rocky Mountain trench (TT-NRMT) $=500-1000 \mathrm{~km}$, Denali fault $(D F)=450 \mathrm{~km}$, and Fraser-Straight Creek fault system (F-SCF) $=100 \mathrm{~km}$ [Price et al., 1985; Gabrielse, 1985; Nokleberg et al., 1985]. See Figure 1 for terrane abbreviations. Figure 3a depicts Middle Jurassic accretion of the AWP followed by evolution of dextral transtensional basins along the Cordilleran margin. The location of the Late Jurassic arc reflects east-directed subduction along the margin, outboard of the AWP. Figure $3 \mathrm{~b}$ depicts Early Cretaceous northward translation of the AWP and San Juan terranes and mid-Cretaceous contractional deformation. 
related structures. Clastic basins along the inboard margin of the AWP likely evolved in this early Late Jurassic dextral regime. Regions east of the AWP were apparently affected as well: the Bowser basin is inferred to have evolved during a period of dextral transtension within the Stikine terrane [Greig et al., 1991] and Late Jurassic plutons east of the Omenica belt were emplaced in a dextral regime [Vogl and Simony, 1991].

Marine clastic sedimentation beginning in Oxfordian time reflects the evolution of transtensional basins along the Cordilleran margin (Figure 3a). Deposition in ophiolite-floored basins south of the AWP is recorded by Oxfordian to Kimmeridgian turbiditic strata that typically interfinger with or overlie arc-related volcanic rocks or contain a significant component of arc-derived detritus. The Constitution and similar assemblages were likely deposited in forearc basins that evolved within the ophiolite basin framework south of the AWP. Concurrent with establishment of a Late Jurassic arc on the AWP, Upper Jurassic strata were deposited along the inboard AWP margin in the Kahiltna and GravinaNutzotin basins. Upper Jurassic volcaniclastic rocks in the Harrison Lake region (Gambier assemblage) and San Juan region (Spieden Group) were deposited in proximity to the southern extension of the AWP arc complex. The Tyaughton-Methow and Bowser basins continued to evolve east of the Late Jurassic arc. Depositional continuity between the northern basins (e.g., GravinaNutzotin-Bowser-Tyaughton-Methow basin of Eisbacher [1985]) was likely but is not demonstrable. Establishing original basin widths is not possible due disruption resulting from mid-Cretaceous and younger deformation inboard of the AWP.

Arguments for left-lateral shear within and along the margin of the Cordillera during Late Jurassic to Early Cretaceous time are presented by Engebretson et al. [1985], Avé Lallemant and Oldow [1988], and May et al [1989]. Saleeby and Busby-Spera [1992] and Plafker et al. [1989] discussed geologic evidence for latest Jurassic to earliest Cretaceous sinistral displacement along the southern Cordilleran margin and within Wrangellia, respectively. A return to northward translation of outboard terranes along the Cordilleran margin is recorded by Hauterivian to Aptian northward dispersal of the Decatur terrane from the Coast Range ophioliteGreat Valley sequence [Garver, 1988b] and Shuksan metamorphic suite from the Franciscan Complex [Brown and Blake, 1987]. Early Cretaceous (post-150 Ma and pre-110 Ma) dextral displacement along the MojaveSnow Lake fault in eastern California [Lahren et al., 1990] may have accommodated the northward translation of these fragments [Burchfiel et al., 1992].

Arc magmatism shifted eastward in Early Cretaceous time such that, with the exception of the Kahiltna terrane, Lower Cretaceous volcanic rocks are common to all of the assemblages along the eastern margin of the AWP and interfinger with clastic strata in the western exposures of the Tyaughton and Methow basins (Figure $3 b)$. Aptian-Cenomanian $(\approx 125-90 \mathrm{Ma})$ plutonic and volcanic rocks east of the Tyaughton-Methow basin [Greig, 1989; Thorkelson and Smith, 1989; Hurlow and Nelson, 1991] and Early Cretaceous blueschists in the Shuksan metamorphic suite in the northern Cascades [Armstrong and Misch, 1987] have been cited by numerous workers as evidence for Early Cretaceous arc magmatism (Spences Bridge arc) associated with east directed subduction and closure of a marginal basin east of the AWP [e.g., Monger, 1986; Thorkelson and Smith,
1989]. Fundamental problems with this interpretation include evidence reviewed above supporting pre-Late Jurassic accretion of the AWP and the distinct lack of any structural evidence for an Early Cretaceous subduction zone within or adjacent to the TyaughtonMethow basin. Early Cretaceous (130-120 Ma) Rb-Sr and $\mathrm{K}-\mathrm{Ar}$ metamorphic ages for the Shuksan suite are alternatively interpreted to record variable midCretaceous resetting of late Middle Jurassic (170-160 Ma) blueschist metamorphic assemblages. We accordingly interpret the Spences Bridge arc to reflect eastward migration Gambier arc magmatism associated with a single subduction zone outboard of the AWP.

East directed underthrusting of the AWP, GravinaNutzotin belt, and Kahiltna basin beneath the YukonTanana and Stikine terranes and northwest directed imbrication in the northwest Cascades-San Juan thrust system in mid-Cretaceous time resulted in a regionally extensive thrust belt extending from southern Alaska to northwestern Washington [Rubin et al., 1990; Gehrels et al., 1992; McClelland et al., 1992b; Rubin and Saleeby, 1992] (Figure 3b). Kinematic relations suggest that thrusting in the northwest Cascades-San Juan system may have occurred in a right-lateral transpressional setting [Brown, 1987; Brown and Talbot, 1989]. A similar setting is envisioned for the mid-Cretaceous underthrusting of the AWP in southeastern Alaska [Coney, 1989; McClelland et al., 1992b], although a sinistral component of underthrusting is locally recorded [Saleeby and Busby-Spera, 1992]. The thrust belt is coincident with a belt of high pressure mid-Cretaceous arc-type plutons that extends southward into the Blue Mountains region [Zen, 1988] which also experienced mid-Cretaceous crustal thickening possibly in a dextral regime [Lund and Snee, 1988].

Mid-Cretaceous deformation along the entire Cordilleran margin either terminated deposition in the marginal basins or is generally marked by a significant unconformity beneath Albian or younger coarse clastic strata. Deformation along the inboard margin of the AWP was broadly synchronous with contraction in the Stikine terrane (Skeena fold belt of Evenchick [1991]) and Omenica belt [Archibald et al., 1983] (Figure 3b). In the southern Cordillera, west directed thrusts involving the Great Valley-Coast Range ophiolite and Franciscan Complex were broadly synchronous with contractional deformation in the Sevier orogenic belt [Lawton, 1985; Heller et al., 1986] and its hinterland [e.g., Miller and Gans, 1989] (Figure 3b). Thus deformation along the inboard margin of the AWP reflects involvement in a Cordilleran-wide contractional event related to a change in subduction zone parameters outboard of the AWP (e.g., increased coupling with the downgoing oceanic slab) rather than the collision of the AWP.

\section{CONCLUSIONS}

Discrepancies between models for the accretionary history of the AWP have for the most part centered on arguments favoring pre-Late Jurassic or mid-Cretaceous accretion or collision. Uncertainty concerning the AWP accretionary history largely results from extensive midCretaceous and younger disruption, overprinting, and modification of possible pre-mid-Cretaceous accretionrelated structures. On the basis of evidence outlined above, we conclude that the AWP was accreted to the Cordilleran margin during Middle Jurassic time. Regional similarities in the character and age of Late 
Jurassic-Early Cretaceous marginal basins common to the AWP and Cordilleran margin reflect the Middle Jurassic accretion of the AWP. The basins are inferred to have evolved within or proximal to transtensional basinal arc complexes that record east directed subduction along the Klamath-Sierra Nevada margin and outboard margin of the AWP. Variations in stratigraphy and provenance observed between basins along the margin resulted from differences in basement composition and proximity to coeval arc volcanism as well as local variation in transtensional and transpressional displacement along the margin. A first-order difference between the northern and southern Cordillera resulted from the kinematic history of the AWP outlined herein. Post-Middle Jurassic evolution of the northern Cordillera was dominated by the presence of the AWP in a forearc position whereas to the south, a thinner belt of Middle to Late Jurassic interarc ophiolite-floored basins evolved and served as basement for the younger Great Valley forearc basin.

Evidence for Middle Jurassic AWP accretion, involvement of the AWP in Late Jurassic-Early Cretaceous basinal evolution along the Cordilleran margin, and similarity in timing of mid-Cretaceous deformation throughout the Cordillera suggest that midCretaceous deformation along the inboard margin of the
AWP was related to a change in subduction zone parameters outboard of the AWP rather than its collision with the Cordilleran margin. In our view, accretion of the AWP was a protracted process of juxtaposition, translation, and imbrication that occurred from Middle Jurassic to mid-Cretaceous time. Although there are still many uncertainties regarding the proposed accretionary history of the AWP, the available evidence demands that the AWP was intimately involved in the Late JurassicEarly Cretaceous evolution of the Cordilleran margin. This involvement must be incorporated into models concerning Mesozoic evolution of the Cordilleran margin.

Acknowledgments. The ideas presented in this paper were strongly influenced by discussions with P. J. Coney, J. W. H. Monger, and C. R. Rubin and are the direct outgrowth of research in southeastern Alaska funded by Geological Society of America, Sigma Xi, and ARCO research grants awarded to McClelland and NSF Grants EAR-8616473 and EAR-8903794 awarded to G. E. Gehrels and EAR-860538 and EAR-8803834 awarded to J. B. Saleeby. C. H. Hopson, J. L. Jackson, and M. M. Miller provided valuable comments on early versions of the manuscript. We thank G. A. Davis, J. O. Wheeler, and $P$. van der Heyden for providing unpublished manuscripts, and J. I. Garver and K. L. Kleinspehn for reviews.

\section{REFERENCES}

Anderson, P., Oceanic crust and arc-trench gap tectonics in southwestem British Columbia, Geology. 4, 443-446, 1976.

Anderson, RG., A stratıgraphic, plutonic, and structural framework for the Iskut River map area, northwestern British Columbia, Pap. Geol. Surv. Can., 89$1 \mathrm{E}, 145-154,1989$.

Anderson, RG., and C.J. Greig, Jurassic and Tertiary plutonism in the Queen Charlotte Islands, Britısh Columbia, Pap. Geol. Surv Can. 89-1H, 95-104, 1989.

Archibald, D.A., J.K. Glover, R.A. Price, E Farrar, and D.M. Carmichael, Geochronology and tectonic implications of magmatism and metamorphism, southem Kootenay are and neighboring regions, southeastem British Columbia - I. Jurassic to mid-Cretaceous, Can. J. Earth Sci.. 20, 1891-1913, 1983.

Armstrong, R.L., Mesozoic and early Cenozoic magmatic evolution of the Canadian Cordillera, Spec. Pap. Geol. Soc. Am., 218, 55-91, 1988.

Armstrong, R.L., and P. Misch, Rb-Sr and KAr dating of mid-Mesozoic blueschist and late Paleozoic albite-epidote-amphibolite and blueschist metamorphism in the North Cascades, Washıngton and British Columbia, and $\mathrm{Sr}$-isotope fingerprinting of eugeosynclinal rock assemblages, Bull. Wash. Div. Geol. Earih Resour., 77, 85 106, 1987.

Arthur, AJ., Stratigraphy along the west side of Harrison Lake, southwestem British Columbia, Pap. Geol. Surv. Can., 86-1B, 715-720, 1986.

Avé Lallemant, H.G., Pre-Cretaceous tectonic evolution of the Blue Mountains Province, northeastem Oregon, U.S. Geol. Surv. Prof Pap. 1438, in press, 1992.

Avé Lallemant, H.G., and J.S. Oldow, Early Mesozoic southward migration of Cordilleran transpressional terranes, Tectonics, 7, 1057-1076, 1988.

Barker, F., Cretaceous Chisana island arc of Wrangellia, eastern Alaska, Geol. Soc. Am. Abstr. Proprams, 19 580, 1988.
Bassett, K., Preliminary results of the sedimentology of the Skeena Group in west-central British Columbia, Pap. Geol. Surv. Can., 91-1A 131-141, 1991.

Berg, H.C., D.L. Jones, and D.H. Richter, Gravina-Nutzotin belt - significance of an upper Mesozoic sedımentary and volcanic sequence in southern and southeastern Alaska, U.S. Geol. Surv. Prof. Pap. 800-D. D1-D24, 1972.

Blake, M.C., Jr., D.C. Engebretson, A.S. Jayko, and D.L. Jones, Tectonostratigraphic lerranes of southwestern Oregon, in Tectonostratıgraphic Terranes of the Circum-Pacific Region. Circum-Pacific Councll for Energy and Min. Resour. Earth Sci. Ser., vol. 1, edited by D.G. Howell, pp. 147-157, American Association of Petroleum Geologists, Tulsa, Okla. 1985.

Box, S.E., and W.W. Patton, Jr., Igneous history of the Koyukuk terrane, western Alaska: Constraints on the origin, evolution, and ultimate collision of an accreted island arc terrane, J. Geophys. Res.. 94, 15,843-15,867, 1989 .

Brandon, M.T., Deformational styles in a sequence of olistostromal mé langes, Pacific Rum Complex, western Vancouver Island, Canada, Geol. Soc. Am. Bull. 101, 1520$1542,1989$.

Brandon, M.T., D.L. Cowan, and J.A. Vance, The Late Cretaceous San Juan thrust system, San Juan Islands, Washington, Spec. Pap. Geol. Soc Am. 221, 81 pp., 1988.

Brew, DA., and S.M. Karl, A reexamination of the contacts and other features of the Gravina belt, southeastern Alaska, U.S. Geol. Surv. Circ. 1016, 143-146, 1988.

Brown, E.H., Structural geology and accretionary history of the Northwest Cascades system, Washington and British Columbia, Geol. Soc. Am Bull. 99, 201214, 1987.

Brown, E.H., and M.C. Blake, Jr., Correlation of Early Cretaceous blueschists in Washington, Oregon and northem California, Tectonics, 6, 795-806, 1987

Brown, E.H., and J.L. Talbot, Orogen-parallel extension in the North Cascades erystallune core, Washington, Tectonics, 8, 1105-1114, 1989.

Brown, R.L., J.M. Journeay, L.S. Lane, D.C Murphy, and C.J. Rees, Obduction, backfolding and piggyback thrusting in the metamorphic hinterland of the southeastem Canadian Cordillera, J. Struct Geol. 8, 255-268, 1986.

Burchfiel, B.C., D.S. Cowan, and G.A. Davis, Tectonic overview of the Cordilleran orogen in the Westem United States, The Geology of North America, vol. G-3, Geological Society of America, Boulder, Colorado, in press, 1992

Butler, R.F., G.E. Gehrels, W.C. McClelland, S.R. May, and D. Klepacki, Discordant paleomagnetic poles from the Canadian Coast Mountains batholith, regional tilt rather than large-scale displacement, Geology, 17, 691-694, 1989.

Coe, R.S., B.R. Globerman, P.W. Plumley, and G.A. Thrupp, Paleomagnetic results from Alaska and their tectonic implications, in Tectonostratipraphic Terranes of the Circum-Pacific Region Circum-Pacific Council for Eneryy and Min. Resour. Earth Sci. Ser., vol. 1, edited by D.G. Howell, Pp. 85-108, American Association of Petroleum Geologists, Tulsa, Okja., 1985.

Coney, P.J., Structural aspects of suspect terranes and accretionary tectonics in western North America, J. Struct. Geol. 11, 107-125, 1989.

Coney, PJ., D.L. Jones, and J.W.H. Monger, Cordilleran suspect terranes, Nature, 288. 329-333, 1980.

Cordey, F., N. Mortimer, P. DeWever, and J.W.H. Monger, Significance of Ju rassic radiolarians from the Cache Creek terrane British Columbia, Geology, 15, 1151-1154, 1987.

Crawford, M.L., L.S. Hollister, and G.J. Woodsworth, Crustal deformation and regional metamorphism across a terrane boundary, Coast plutonic complex, British Columbia, Tectonics, 6, 343-361, 1987

Csejtey, B., Jr., D.P. Cox, R.C. Evarts, G.D. Stricker, and H.L. Foster, The Cenozoic 
Denali fault system and the accretionary history of southern Alaska, J. Geophys. Res., 87, 3741-3754, 1982.

Davis, G.A., J.W.H. Monger, and B.C Burchfiel, Mesozoic construction of the Canadian Cordilleran "collage", central British Columbia to central California, in Mesozoic Paleogeography of the Wesiern United States, Pacific Coast Paleogeography Symposium 2 , edited by D.G. Howell and K.A. McDougall, pp. 132, Pacific Section, Society of Economic Paleontologists and Mineralogists, Los Angeles, Calif., 1978

Dickınson, W.R, and E.I. Rich, Petrologic intervals and petrofacies in the Great Valley sequence, Sacramento Valley, California, Geol. Soc. Am. Bull., 83, 3007. 3024,1972

Dickinson, W.R, and T.P. Thayer, Paleogeographic and paleotectonic implications of Mesozoic stratigraphy and structure in the John Day inlier of Central Oregon, in Mesozoic Paleogeography of the Westerm United States, Pacific Coast Paleogeography Symposium 2, edited by D.G. Howell and K.A. McDougall, Pp. 147-161. Pacific Section, Society of Economic Paleontologists and Mineralogists, Los Angeles, Calif., 1978.

Dodds, C.J., and R.B. Campbell, PotassiumArgon ages of mainly intrusive rocks in the Sarnt Elias Mountains, Yukon and Bntish Columbia, Pap. Geol. Surv. Can. 87-16, 43 pp., 1988.

Douglas, B.J., Deformational history of an outlier of metasedimentary rocks, Coast Plutonic Complex, British Columbia, Canada, Can. J. Earth Sci. 23, 813-826, 1986.

Eisbacher, G.H., Sedimentology of the Dezadeash flysch and its implications for strike-slip faulting along the Denali fault. Yukon Territory and Alaska, Can. J. Earth Sci. 13, 1495-1513, 1976.

Eisbacher, G H., Pericollisional strike-slip faults and synorogenic basins, Canadian Cordillera, in Strke-slip Deformation, Basin Formation, and Sedimentation, edited by K.T. Biddle, and N. ChristieBlick, Soc. Econ. Paleontol. Mineral. Spec. Publ.. 37, 265-282, 1985.

Engebretson, D.C., A. Cox, and R.G. Gordon, Relative motions between oceanic and continental plates in the Pacific basin, Spec. Pap. Geol. Soc. Am., 206, 59 PP., 1985.

Evenchick, C.A., Geometry, evolution, and tectonic framework of the Skeena fold belt, north central British Columbia. Tectonics, 10, 527-546, 1991.

Friedman, R.M., U-Pb dating of Jurassic and Cretaceous igneous rocks from the southem Coast belt, $\left(49^{\circ}-51^{\circ} \mathrm{N}\right)$, B.C. Geol. Soc. Am. Abstr. Programs, 21, A269, 1989.

Fredman, R.M., J.W.H. Monger, and H.W. Tipper, Age of the Bowen Island Group, southwestem Coast Mountains, British Columbia, Can. J. Earth Scl., 27, 14561461, 1990 .

Gabrielse, H., Major dextral iranscurrent displacements along the Northern Rocky Mountann Trench and related lineaments in north-central Britısh Columbia, Geol. Soc. Am. Bull., 96, 1-14, 1985.

Garcia, M.O., Petrology of the Rogue River island-arc complex, southwest Oregon, Am. J. Sci. 282, 783-807, 1982.

Gardner, M.C., S.C. Bergman, G.W. Cushing, E.M. MacKevett, Jr., G. Plafker, RB. Campbell, C.J. Dodds, W.C. McClelland, and P.A. Mueller, Pennsylvanian pluton stitching of Wrangellia and the Alexander terrane, Wrangell Mountains, Alaska, Geology, 16, 967-971, 1988.
Gareau, S.A., The Scotia-Quaal metamorphic belt: a distinct assemblage with pre-early Late Cretaceous deformational and metamorphic history, Coast Plutonic Complex, B.C., Can. J. Earih Sci., 28, 870$880,1991$.

Garver, J.I., Stratıgraphy, depositional setting, and tectonic significance of the clastic cover to the Fidalgo ophiolite, San Juan Islands, Washington, Can. J. Earth Sci. 25, 417-432, 1988a.

Garver, J.I., Fragment of the Coast Range ophiolite and the Great Valley sequence in the San Juan Islands, Washington, Geology, 16, 948-951, 1988 b.

Garver, J.I., Basin evolution and source terranes for Albian-Cenomanian rocks in the Tyaughton basin, southern British Columbia: Implications for mid-Cretaceous tectonics in the Canadian Condillera, Ph.D. thesıs, 227 pp., Univ. of Wash., Seattle, 1989.

Garver, J.I., M.F. McGroder, PJ. Umhoefer, and J. Bourgeois, Pre- to syn-collisional sedimentation in the Jura-Cretaceous Methow-Tyaughton basin, northern Washington, southern British Columbia, Geol. Soc. Am. Abstr. Programs, 20,274 , 1988.

Gehrels, G.E., and H.C. Berg, A review of the regional geology and tectonics of southeastern Alaska, U.S. Geol. Surv. Open File Rep., 88-659, 23 pp., 1988

Gehrels, G.E., and C.J. Greig, Late Jurassic detrital zircon link between the AlexanderWrangellia terrane and Stikine and YukonTanana terranes, Geol. Soc. Am. Abstr Programs, 23, A434, 1991.

Gehrels, G.E., and J.B. Saleeby, Constraints and speculations on the displacement history of the

Alexander-Wrangella-Peninsular superterrane, Geol. Soc. Am. Abstr. Prowrams, 17, 356, 1985.

Gehrels, G.E., and J.B. Saleeby, Geologic framework, tectonic evolution, and displacement history of the Alexander terrane, Tectonics, 6, 151-174, 1987.

Gehrels, G.E., W.C. McClelland, S.D. Samson, P.J. Patchett, and J.L. Jackson, Ancient continental margin assemblage in the northern Coast Mountains, southeast Alaska and northwest Canada, Geology, 18, 208-211, 1990

Gehrels, G.E., W.C. McClelland, S.D. Samson, P.J. Patchett, and M.J. Orchard, Geology of the westem flank of the Coast Mountains between Cape Fanshaw and Taku Inlet, southeastem Alaska, Tectonics, in press, 1992.

Gordon, R.G., A. Cox, and S. O'Hare, Paleomagnetic Euler poles and the apparent polar wander and absolute motion of North America since the Carboniferous, Tectonics, 3. 499-537, 1984.

Greig, CJ., Deformation and plutonism in the Eagle complex, Coquihalta area, B.C. Implications for Late Jurassic deformation along the western margin of Quesnellia and constraints on mid-Cretaceous motion along the Pasayten fault, Geol. Soc. Am. Abstr. Programs, 21, 37, 1989.

Greig, C.J., G.E. Gehrels, R.G. Anderson, and $\mathrm{CA}$. Evenchick, Possible transtensional origin for the Bowser basin, British Columbia, Geol. Soc. Am. Abstr. Proprams, 23, 30, 1991

Haeussler, PJ., R.S. Coe, T.C. Onstott, and P. Renne, A second look at the paleomagnetism of the Late Triassic Hound Island Volcanics of the Alexander terrane (abstract), Eos Trans. AGU, 70 $1068,1989$.

Haggart, J.W., A synthesis of Cretaceous stratigraphy, Queen Charlotte Islands, British Columbia, in Evolution and
Hydrocarbon Potential of the Queen Charlotte Basin, British Columbia, edited by GJ. Woodsworth, Pap. Geol. Surv Can., 90-10, 253-277, 1991

Harper, G.D., and J.E. Wright, Middle to Late Jurassic tectonic evolution of the Klamath Mountains, Califomia-Oregon, Tectonics, 3, 759-772, 1984.

Heller, P.L., S.S. Bowdler, H.P. Chambers, J.C. Coogan, E.S. Hagen, M.W. Shuster N.S. Winslow, and T.F. Lawton, Time of initial thrusting in the Sevier orogenic belt, Idaho-Wyoming and Utah, Geology, 14, 388-391, 1986.

Hıggs, R, Sedımentology and tectonic implications of Cretaceous fan-delta conglomerates, Queen Charlotte Islands, Canada, Sedimentolory, 37, 83-103, 1990.

Hillhouse, J.W., and C.S. Gromme, Northward displacement and accretion of Wrangellia: new paleomagnetic evidence from Alaska, J. Geophys. Res. 89, 4461.

4477, 1984.
Hopson, C.A., J.M. Mattinson, and C.A. Pessagno, Coast Range ophiolite, western California, in The Geotectonic

Development of California, edited by W.G. Ernst, pp. 418-510, Prentice-Hall, Englewood Cliffs, N. J., 1981.

Hopson, C., W. Beebe, J. Mattinson, E. Pessagno, and C. Blome, California Coast Range ophiolite (CRO): Middle Jurassic/central tethyan and latest Jurassic/southem boreal episodes of ocean ndge magmatism (abstract), Eos Trans AGU, 72, 443, 1991.

Hudson, T., Calc-alkaline plutonism along the Pacific rim of southern Alaska, Mem. Geol. Soc. Am., 159, 159-170, 1983.

Hurlow, H.A., and B.K. Nelson, U-Pb ages for the Okanagan Range batholith, Washington: Evidence for middle Cretaceous Cordilleran arc magmatism, Geol. Soc. Am. Abstr. Programs, 23,37 , 1991

Ingersoli, RV., Petrofacies and provenance of late Mesozoic forearc basin, northem and central California, AAPG Bull. 67, 1125 $1142,1983$.

Jeletzky, J.A., Jurassic-Cretaceous boundary beds of western and Arctic Canada and the problem of the Tithonian-Berriasian stages in the boreal realm, Geol. Assoc. Can. Spec. Pap. 27, 175-255, 1984.

Jeletzky, J.A., and H.W. Tipper, Upper Jurassic and Cretaceous rocks of the Taseko Lakes map-area and their bearing on the geological history of southwestern British Columbia, Pap. Geol. Surv. Can. 67-54, 218 pp., 1968

Jett, G.A., and P.L. Heller, Tectonic significance of polymodal compositions in mé lange sandstones, western mé lange belt north Cascade Range, Washington, $\underline{\mathbf{J}}$. Sediment. Petrol. 58, 52-61, 1988.

Johnson, S.Y., The Spieden Group: an anomalous piece of the Cordilleran paleogeographic puzzle, Can. J. Earth Sci. 14, 2565-2577, 1981.

Jones, D.L., W.P. Irwin, and A.T. Ovenshine, Southeastem Alaska - a displaced continental fragment, U.S. Geol. Surv. Prof. Pap., 800-B, B211-B217, 1972.

Jones, D.L., NJ. Silberling, and J. Hillhouse, Wrangellia - a displaced terrane in northwestem North America, Can. J. Earth Sci. 14, 2565-2577, 1977.

Jones, D.L., NJ. Silberling, PJ. Coney, and G. Plafker, Lithotectonic terrane map of Alaska, U.S. Geol. Surv. Misc. Field Stud. Map. MF-1874-A, 1987.

Jones, D.L.. N.J. Silberling, W. Gilbert, and P. Coney, Character, distribution, and tectonic significance of accretionary terranes in the central Alaska Range, J. Geophys. Res., 87 3709-3717, 1982. 
Jones, D.L., N.J. Silberlıng, and PJ. Coney, Collision tectonies in the Cordillera of western N. America: Examples from Alaska, in Collision Tectonics, edited by M.P. Coward and A.C. Ries, Geol. Soc. Spec. Publ. London, 19, 367-387, 1986.

Journeay, J.M., A progress report on the structural and tectonic framework of the southern Coast Belt, Bntish Columbia, Pap. Geol. Surv. Can., 90-1E, 183-195, 1990.

Kleinspehn, K.L., Cretaceous sedimentation and tectonics, Tyaughton-Methow Basin, southwestern Britısh Columbia, Can. J. Earth Sci., 22, 154-174, 1985.

Lahren, M.M., R.A. Schweickert, J.M Mattinson, and J.D. Walker, Evidence for uppermost Proterozoic to lower Cambrian miogeoclinal rocks and the Mojave-Snow Lake fault: Snow Lake pendant, central Sierra Nevada, California, Tectonics, 9 1585-1608, 1990.

Lawton, T.F., Style and tuming of frontal structures, thrust belt, central Utah, AAPG Bull. 69, 1145-1159, 1985.

Lewis, P.D., J.W. Haggart, R.G. Anderson, C.J. Hickson, R.I. Thompson, J.R. Dietrich, and K.M.M. Rohr, Triassic to Neogene geologic evolution of the Queen Charlotte region, Can. J. Earth Sci., 28, 854-869, 1991.

Lund, K, and L.W. Snee, Metamorphism, structural development, and age of the continent:island arc juncture in west-central Idaho, in Metamorphism and Crustal Evolution of the Westem United States. edited by W.G. Ernst, pp. 296-331, Prentice-Hall, Englewood Clifts, N. J., 1988.

May, S.R., and R.F. Butler, North American apparent polar wander. Implications for plate motion, paleogeography, and Cordilleran tectonics, J Geophys. Res., 91 11,519-11,544, 1986.

May, S.R., M.E. Beck, Jr., and R.F. Buller, North American apparent polar wander, plate motion, and left-oblique motion: Late Jurassic-Early Cretaceous orogenic consequences, Tectonics, 8, 443-452, 1989.

McClelland, W.C., and G.E. Gehrels, Geology of the Duncan Canal shear zone: evidence for Eariy-Middle Jurassic deformation of the Alexander terrane, southeastem Alaska, Geol. Soc. Am. Bull., 102, 1378 1392, 1990.

McClelland, W.C., G.E. Gehrels, S.D. Samson, and P.J. Patchett, Protolith relations of the Gravina belt and Yukon-Tanana terrane in central southeastem Alaska, J. Geol., 100, 107-123, 1992a.

McClelland, W.C., G.E. Gehrels, S.D. Samson, and PJ. Patchett, Structural and geochronologic relations along the western flank of the Coast Mountains batholith: Stıkine River to Cape Fanshaw, central southeastern Alaska, J. Struct. Geol.. 14 475-489, $1992 \mathrm{~b}$.

McGroder, M.F., Structural geometry and kinematic evolution of the eastern Cascades foldbelt, Washington and British Columbia, Can. J. Earth Sci., 26, 1586$1602,1989$.

McGroder, M.F., Reconcilation of two-sided thrusting, bunal metamorphism, and drachronous uplift in the Cascades of Washıngton and British Columbia, Geol. Soc. Am. Bull. 103, 189-209, 1991.

McGroder, M.F., J.I. Garver, and V.S. Mallory, Bedrock geologic map, biostratigraphy, and structure sections of the Methow Basin, Washington and British Columbia, Open File Rep. Wash. Div. Geol. Earth Resour., 90-19, 32 pp., 1990.

Miller, E.L., and P.B. Gans, Cretaceous crustal structure and metamorphism in the hinterland of the Sevier thrust belt, western U.S. Cordillera, Geology, 17, 5962, 1989 .

Miller, M.M., Dispersed remnants of a northeast Pacific fringing arc: upper Paleozoic terranes of Permian McCloud faunal affinity, western U.S., Tectonics, 6, 807-830, 1987.

Miller, RB., The ophılitıc Ingalls Complex, north-central Cascade Mountains, Geol. Soc. Am. Bull., 96, 27-42, 1985 .

Miller, RB., The Mesozoic Rimrock Lake inlier, southem Washington Cascades: Implications for the basement to the Columbia Embayment, Geol. Soc. Am. Bull. 101, 1289-1305, 1989

Misch, P., Tectonic evolution of the northern Cascades of Washington State, Spec. Vol. Can. Inst. Min. Metall. 8, 101-148, 1966.

Monger, J.W.H., Geology between Harrison Lake and Fraser River, Hope map area, southwestern British Columbia, Pap. Geol. Surv. Can. 86-1B, 699-706, 1986.

Monger, J.W.H, Geology of Hope map area, British Columbia, Map Geol. Surv. Can. 41-1989, 1989.

Monger, J.W.H., R.A. Price, and D.J. Tempelman-Kluit, Tectonic accretion and the origin of the two major metamorphic welts in the Canadian Cordillera, Geology. 10, 70-75, 1982.

Mortimer, N., Late Truassic, arc-related, potassic ugneous rocks in the North American Cordillera, Geology. 14, 1035 1038, 1986.

Muller, J.E., B.E.B. Cameron, and K.E Northcote, Geology and mineral deposits of Nootka Sound map area (92E), Vancouver Island, British Columbia, Pap. Geol. Surv. Can., 80-16, 53 pp., 1981

Newton, C.R, Paleozoogeographic aftinities of Norian bivalves from the Wrangellian, Peninsular, and Alexander terranes, western North America, in Pre-Jurassic

Rocks in Western North American Suspect Terranes, edited by C.H. Stevens, pp. 3748, Pacific Section, Society of Economic Paleontologists and Mineralogists, Los Angeles, Calif., 1983.

Nokleberg, WJ., D.L. Jones, and N.J. Silberling, Origin and lectonic evolution of the Maclaren and Wrangellia terranes, castern Alaska Range, Alaska, Geol. Soc. Am. Bull. 96, 1251-1270, 1985

Oldow, J.S., A.W. Bally, H.G. Avé Lallemant, and W.P. Leeman, Phanerozoic evolution of the North American Cordillera, in The Geology of North Amenca, vol. A, An Overview, edited by A.W. Bally and A.R. Palmer, pp. 139-232, Geological Society of America, Boulder, Colo., 1989.

Palmer, A.R. The Decade of North American Geology time scale, Geology, $11,503-504$, 1983.

Pavlis, T.L., Origin and age of the Border Ranges fault of southem Alaska and its bearing on the late Mesozoic tectonic evolution of Alaska, Tectonics, 1, 343-368, 1982.

Pavlis, T.L., Middle Cretaceous orogenesis in the northem Cordillera: a Mediterranean analog of collision-related extensional tectonics, Geology. 17, 947-950, 1989.

Pessagno, EA., and C.D. Blome, Implications of new Jurassic stratigraphic,

geochronometric, and paleolatitudinal data from the western Klamath terrane (Smith River and Rogue Valley subterranes), Geology, 18, 665-668, 1990.

Plafker, G., WJ. Nokleberg, and J.S. Lull, Bedrock geology and tectonic evolution of the Wrangellia, Penınsular, and Chugach terranes along the southern margin of the Trans-Alaska Crustal Transect in the Chugach Mountains and southem Copper
River basin, Alaska, J. Geophys. Res., 94. 4255-4295, 1989

Price, RA., The Cordilleran foreland thrust and fold belt in the southern Canadian Rocky Mountains, in Thrust and Nappe Tectonics, edited by K.R. McClay and NJ. Price, Geol. Soc. Spec. Publ. London, 9, 427-448, 1981

Price, R.A., J.W.H. Monger, and J.A Roddick, Cordilleran cross-section, Calgary to Vancouver, in Field Guides to Geology and Mineral Deposits in the Southern Canadian Cordillera, edited by $D$. Tempelman-Kluit, pp. 3-1-3-85, Geological Association of Canada, Vancouver, B. C., 1985.

Rubın, C.M., and J.B. Saleeby, Tectonic framework of the upper Paleozoic and lower Mesozotc Alava sequence: a revised view of the polygenetic Taku terrane in southem Alaska, Can. J. Earth Sci., 28 . 881-893, 1991a.

Rubin, C.M., and J.B. Saleeby, The Gravina sequence: remnants of a mid-Mesozoic oceanic arc complex in southem southeast Alaska, J. Geophys. Res., 96, 14,551-14,568, 19916.

Rubin, C.M., and J.B. Saleeby, Thrust tectonics and Cretaceous intracontinental shortening in southeast Alaska, in Thrust Tectonies, edited by $\mathrm{K}$. McClay, Unwin Hyman, Cambridge, Mass., in press, 1992.

Rubin, C.M., J.B. Saleeby, D.S. Cowan, M.T Brandon, and M.F. McGroder, Regionally extensive mid-Cretaceous west-vergent thrust system in the northwestem Cordillera: Implications for continental margin tectonism, Geology, 18, 276-280, 1990.

Rusmore, M.E., and D.S. Cowan, JurassicCretaceous rock units along the southem edge of the Wrangellia terrane on Vancouver Island, Can. J. Earth Sci.,22 1223-1232, 1985

Rusmore, M.E., and G.J. Woodsworth, A note on the Coast-Intermontane belt transition, Mt. Waddington map area, British Columbia, Pap. Geol. Surv. Can. 89-1E, 163-167, 1989.

Rusmore, M.E., and G.J. Woodsworth, Distribution and tectonic significance of Upper Triassic terranes in the eastern Coast Mountains and adjacent Intermontane belt, British Columbia, Can. J. Earth Sci., 28, 532-541, 1991.

Rusmore, M.E., C.J. Potter, and P.J. Umhoefer, Middle Jurassic terrane accretion along the western edge of the Intermontane superterrane, southwestem British Columbıa, Geology. 16, 891-894, 1988.

Saleeby, J.B., Polygenetic ophiolite belt of the Calıfornıa Sierra Nevada: Geochronological and tectonostratigraphic development, $\underline{J}$. Geophys. Res., 87, 1803-1824, 1982.

Saleeby, J.B., Accretionary tectonics of the North American Cordillera, Annu. Rev. Earth Planet. Scl., 15, 45-73, 1983.

Saleeby, J.B., C-2 central California offshore to Colorado Plateau, Centen. Continent/Ocean Transect Ser. vol. 10, 63 pp., Geological Society of America, Boulder, Colo., 1986.

Saleeby, J.B., Petrotectonic and paleogeographic settings of U.S. Cordilleran ophiolites, The Geology of North America, vol. G-3, Geological Society of America, Boulder, Colo., in press, 1992.

Saleeby, J.B., and C. Busby-Spera, Early Mesozoic tectonic evolution of the westem U.S. Cordillera, The Geology of North America, vol. G-3, Geological Society of Amenca, Boulder, Colo., in press, 1992. Saleeby, J.B., and G.E. Gehrels, The interplay of accretionary and attritionary tectonics 
along the Calıfornia margin, in The Ocean Basins and Margins, vol. $7 \mathbf{B}$, The Pacific Ocean, edited by A.E.M. Nairn et al., pp. 119-160, Plenum, New York, 1988.

Saleeby, J.B., and C.M. Rubun, Tectonic intercalations of crystalline nappes and basinal overlap relations in southem SE Alaska: implications for the initial stages of Insular superterrane accretion (abstract) Eos Trans. AGU, 71, 1591, 1990.

Samson, S.D., W.C. McClelland, PJ. Patchett, G.E. Gehrels, and R.G. Anderson, Nd isotopes and Phanerozoic crustal genesis in the Canadian Cordillera, Nature, 337, 705709, 1989.

Samson, S.D., PJ. Patchett, G.E. Gehrels, and RG. Anderson, $\mathrm{Nd}$ and $\mathrm{Sr}$ isotopic characterization of the Wrangellia terrane and implications for crustal growth of the Canadian Cordillera, J. Geol. 98, 749-762, 1990.

Seiders, V.M., Origin of conglomerate stratigraphy in the Franciscan assemblage and Great Valley sequence, northem California, Geology. 16, 738-787, 1988.

Sharp, W.D., Pre-Cretaceous crustal evolution in the Sierra Nevada region, Califomia, in Metamorphism and Crustal Evolution of the Western United States, edited by W.G. Ernst, pp. 823-864, Prentice-Hall, Englewood Cliffs, N. J., 1988.

Silberling, N.J., Biogeographic significance of the Upper Triassic bivalve Monotis in Circum-Pacific accreted terranes, in Tectonostratipraphic Terranes of the Circum-Pacific Region, Circum-Pacific Council for Energy and Min. Resour. Earth Sci. Ser., vol. 1, edited by D.G. Howell, pp. 63-70, American Association of Petroleum Geologists, Tulsa, Okla., 1985.

Silberling. N.J., D.L. Jones, M.C. Blake, Jr., and D.G. Howell, Lithotectonic terrane map of the western conterminous United States, U.S. Geol. Surv. Misc. Field Stud. Map. MF-1874-C, 20 pp., 1987.

Smith, P.L., and H.W. Tipper, Plate tectonics and paleobiogeography. Early Jurassic (Pliensbachian) endemism and diversity, Palaios, 1, 399-412, 1986.

Snoke, A.W., A thrust plate of ophiolitic rocks in the Preston Peak area, Klamath Mountains, California, Geol. Soc. Am. Bull. 88, 1641-1659, 1977.

Stanley, W.D., V.F. Labson, W.J. Nokleberg, B. Csejtey, Jr., and M.A. Fischer, The Denali fault system and Alaska Range of Alaska: evidence for underplated Mesozoic flysch from magnetotelluric surveys, Geol. Soc. Am. Bull., 102, 160-173, 199

Stone, D.B., and M.O. McWilliams, Paleomagnetic evidence for relative terrane motion in westem North America, in The Evolution of the Pacific Ocean Marpins edited by Z. Ben-Avraham, Pp. 53-72, Oxford University Press, New York, 1989
Tabor, RW., RA. Haugerud, R.B. Miller, E.H. Brown, and R.S. Babcock, Accreted terranes of the North Cascades Range. Washıngton, Fieldtrip Guidebook T-307, 62 pp, 28th International Geological Congress, Washıngton, D.C., 1989.

Taylor, D.G., J. Callomon, R. Hall, P.L. Smith, H.W. Tipper, and G.E.G. Westerman, Jurassic ammonite biogeography of western North America: the tectonic implicatıons, Geol. Assoc. Can. Spec. Pap., 27, 121-141, 1984

Thorkelson, D., and A.D. Smith, Arc and intraplate volcanism in the Spences Bridge Group: implications for Cretaceous tectonics in the Canadian Cordillera, Geology. 17, 1093-1096, 1989

Tipper, H.W. The allochthonous JurassicEarly Cretaceous terranes of the Canadian Cordillera and their relation to correlative strata of the North American craton, Geol. Assoc. Can. Spec. Pap. $27,113-120,1984$.

Tozer, E.T., Marine Triassic faunas of North America: their signıficance for assessing plate and terrane motions, Geol. Rundsch. 270, 1077-1104, 1982.

Umhoefer, P.J., Northward translation of "Baja British Columbia" along the Late Cretaceous to Paleocene margin of western North America, Tectonics, 6, 377-394, 1987

Umhoefer, PJ., Stratigraphy and tectonic setting of the upper Cadwallader terrane and overlying Relay Mountain Group, and the Cretaceous to Eocene structura evolution of the eastern Tyaughton basin, Bntish Columbia, Ph.D. thesis, 186 pp., Univ. of Wash., Seattle, 1989.

Umhoefer, PJ., Stratigraphy and tectonic setting of the upper part of the Cadwallader terrane, southwestem British Columbia, Can. J. Earth Sci. 27, 702-711, 1990.

Vallier, T.L., The Permıan and Triassic Seven Devils Group, westem Idaho and northeastern Oregon, U.S. Geol. Surv. Bull. 1437, 58 pp., 1977.

van der Heyden, P., A Middle Jurassic to carly Tertiary Andean-Sierran subduction model for the Coast Belt of British Columbia, Tectonics, 11, 82-97, 1992.

Vogl, J.J., and P.S. Simony, The tail of the Nelson batholith: structure and emplacement, Geol. Soc. Am. Abstr. Proprams, 23, 106, 1991

Wahrhaftig, C., D.L. Tumer, F.R Weber, and T.E. Smith, Nature and timing of movement on Hines Creek strand of the Denali fault system, Alaska, Geology, 3 463-466, 1975

Wallace, W.K, C.L. Hanks, and J.F. Rogers, The southern Kahiltna terrane: implications for the tectonic evolution of southern Alaska, Geol. Sor. Am. Bull.. 101, 1389 $1407,1989$.

Wernicke, B., and D.W. KJepacki, Escape hypothesis for the Stıkıne block. Geology. $16,461-464,1988$.

Wheeler, J.O., and P. McFeely, Tectonic assemblage map of the Canadian Cordillera, Open File Rep. Geol. Surv. Can. 1565, 1987.

Wheeler, J.O., A.J. Brookfield, H. Gabrielse, J.W.H. Monger, H.W. Tipper, and G.J Woodsworth, Terrane map of the Canadian Cordillera, Open File Rep. Geol. Surv, Can.. 1894, 1988.

Whetten, J.T., R.E. Zartman, R.J. Blakely, and D.L. Jones, Allochthonous Jurassic ophiolite in northwest Washıngton, Geol. Soc. Am. Bull., 91, 359-368, 1980.

Woodsworth, G.J., and J.W.H. Monger, Upper Jurassic to Paleogene assemblages - the Coast belt, The Geology of North Amenca, vol. G-2, Geological Society of America, Boulder, Colo., in press, 1992.

Woodsworth, G.J., and M.J. Orchard, Upper Paleozoic to lower Mesozoic strata and their conodonts, western Coast Plutonic Complex, British Columbia, Can. J. Earth Sci. 22, 1329-1344, 1985.

Wright, J.E., and M.R. Fahan, An expanded view of Jurassic orogenesis in the westem United States Cordillera: Middle Jurassic (pre-Nevadan) regional metamorphism and thrust faulting whthin an active arc environment, Klamath Mountains, California, Geol. Soc. Am. Bull., 100, 859. 876, 1988.

Wnght, J.E., and S.J. Wyld, Significance of xenocrystic Precambrian zircon contained within the southern continuation of the Josephine ophiolite: Devils Elbow ophiolite remnant, Klamath Mountains, northern Califomia, Geolory. 14, 671-674, 1986.

Wyld, S.J., and J.E. Wright, The Devils Elbow ophiolite remnant and overtying Galice Formation: new constraints on the Middle to Late Jurassic evolution of the Klamath Mountains, California, Geol. Soc. Am. Bull. 100, 29-44, 1988.

Zen, E.A., Tectonic significance of highpressure plutonic rocks in the westem Cordillera of North America, in Metamorphism and Crustal Evolution of the Western United States, edited by W.G. Ernst, pp. 41-68, Prentice-Hall, Englewood Cliffs, N. J., 1988

W. C. McClelland, Department of Geological Sciences, University of California, Santa Barbara, CA 93106.

G. E. Gehrels, Department of Geosciences, University of Arizona, Tucson, AZ 85721

J. B. Saleeby, Division of Geological and Planetary Sciences, California Institute of Technology, Pasadena, CA 91125.

(Received May 17, 1991; revised January 27, 1992;
accepted January 29, 1992. 